\title{
Osmotic Regulation of Estrogen Receptor- $\beta$ in Rat Vasopressin and Oxytocin Neurons
}

\author{
Suwit J. Somponpun and Celia D. Sladek \\ Department of Physiology and Biophysics, University of Colorado Health Sciences Center, Denver, Colorado 80262
}

\begin{abstract}
The vasopressin (VP) magnocellular neurosecretory cells (MNCs) in the supraoptic and paraventricular (PVN) nuclei are regulated by estrogen and exhibit robust expression of estrogen receptor (ER)- $\beta$. In contrast, only $\sim 7.5 \%$ of oxytocin (OT) MNCs express ER- $\beta$. We examined the osmotic regulation of ER- $\beta$ mRNA expression in MNCs using quantitative in situ hybridization histochemistry. Hyperosmolality induced via $2 \%$ hypertonic saline ingestion significantly decreased, whereas sustained hypo-osmolality induced via d-Darginine VP and liquid diet increased ER- $\beta$ mRNA expression in MNCs $(p<0.05)$. Thus, the expression of ER- $\beta$ mRNA correlated inversely with changes in plasma osmolality. Because hyper-osmolality is a potent stimulus for VP and OT release, this suggests an inhibitory role for ER- $\beta$ in MNCs. Immunocytochemistry demonstrated that the decrease in ER- $\beta$ mRNA was translated into depletion of receptor protein content in hyper-osmotic animals. Numerous MNCs were positive for ER- $\beta$ in control animals, but they were virtually devoid of ER- $\beta$-immunoreactivity (IR) in hyper-osmotic animals. The osmotically induced decrease in ER- $\beta$ expression was selective for MNCs because ER- $\beta$-IR remained unaltered in PVN parvocellular neurons. Plasma estradiol and testosterone were not correlated with ER- $\beta$ mRNA expression after osmotic manipulation, suggesting that ER- $\beta$ expression was not driven by ligand availability. Expression of FOS-IR in MNCs with attenuated ER- $\beta$-IR, and the absence of FOS-IR in parvocellular neurons that retain ER- $\beta$-IR suggest a role for neuronal activation in the regulation of ER- $\beta$ expression in MNCs. Thus, osmotic modulation of ER- $\beta$ expression in MNCs may augment or attenuate an inhibitory effect of gonadal steroids on VP release.
\end{abstract}

Key words: in situ hybridization; oxytocin; vasopressin; salt loading; hyponatremia; FOS; supraoptic nucleus; paraventricular nucleus; parvocellular neurons; magnocellular neurosecretory neurons

\section{Introduction}

Systemic vasopressin (VP) and oxytocin (OT) are chiefly produced by magnocellular neurosecretory cells (MNCs) in the supraoptic (SON) and paraventricular (PVN) nuclei of the hypothalamus. In the periphery, VP is involved in maintaining osmotic balance by promoting reabsorption of water in the collecting ducts of the renal tubules and in maintaining blood pressure through vasoconstriction. Its synthesis and secretion is, in turn, controlled by plasma osmolality, as well as by blood pressure and volume (Sladek, 2000). On the other hand, the principal functions of OT secreted by the neurohypophysis are related to reproduction: it is essential for milk ejection and is important in promoting established parturition (Russell and Leng, 1998). In rats, OT is also natriuretic, involving a stimulatory action on atrial natriuretic peptide secretion (Jankowski et al., 1998) and thus contributes to maintenance of electrolyte homeostasis. Its secretion is also regulated by changes in plasma osmolality (Sladek, 2000).

A role for gonadal steroids in regulation of VP and OT secretion was suggested by early reports of gender differences in plasma VP and stimulation of OT release by estrogen (Skowsky et al., 1979; Amico et al., 1981). However, disparate results from

Received Dec. 26, 2002; revised Feb. 20, 2003; accepted Feb. 26, 2003.

This work was supported by American Heart Association Grant $0120582 Z$ (S.J.S.) and National Institutes of Health Grant NS27975 (C.D.S.)

Correspondence should be addressed to Dr. Celia D Sladek, Department of Physiology and Biophysics, University of Colorado Health Sciences Center, 4200 East Ninth Avenue, C240, Denver, CO 80262. E-mail: celia.sladek@uchsc.edu.

Copyright $\odot 2003$ Society for Neuroscience $\quad$ 0270-6474/03/234261-09\$15.00/0 gonadectomy and hormone replacement studies and opposite actions of gonadal steroids in vivo and in vitro made the role of gonadal steroids unclear (Crowley and Amico, 1993; Swenson and Sladek, 1997). Since the cloning of estrogen receptor (ER)- $\beta$, many studies have demonstrated ER- $\beta$ expression in MNCs (Shughrue et al., 1996, 1998; Alves et al., 1998; Hrabovszky et al., 1998; Laflamme et al., 1998), suggesting the potential for direct regulation of MNCs by estrogen. Moreover, because testosterone (T) can be aromatized into estrogen in the hypothalamus (Lephart, 1996) and because the androgen receptor is not expressed in MNCs, it is conceivable that effects of T could also be mediated through ER- $\beta$. In fact, we demonstrated that an antagonist of ER- $\beta$ prevents estradiol $\left(\mathrm{E}_{2}\right)$ inhibition of stimulated VP release from explants of the hypothalamo-neurohypophyseal system (HNS) (Somponpun and Sladek, 2002). Because of the eminent role of receptors for mediating the biological effects of steroid hormones, changes in receptor expression could alter responsiveness of the target cells and determine the physiological circumstances in which gonadal steroids become important regulators of cell function. Therefore, we evaluated the effect of osmotic regulation of VP and OT release on ER- $\beta$ expression in SON and PVN to provide insight into the physiological role of gonadal steroids in the regulation of VP and OT secretion.

In rats, $72 \mathrm{hr}$ of $2 \%$ hypertonic saline ingestion causes increased plasma osmolality and intracellular dehydration. It leads to induction of both VP and OT mRNA production (Van Tol et al., 1987; Carter et al., 1993), depletion in their neural lobe content (Jones and Pickering, 1969; O’Keefe et al., 1995), and increased plasma concentrations of both peptides (Brimble et al., 
1978; Wade et al., 1983). In contrast, hypo-osmolality induced by elevated water intake and water retention inhibits VP and OT secretion (Verbalis, 1984). These two paradigms were used to examine the regulation of ER- $\beta$ mRNA and protein expression in SON and PVN.

\section{Materials and Methods \\ Animals}

Adult male Sprague Dawley rats (250-300 gm; Charles River Laboratories, Wilmington, MA) were housed in groups of three and maintained on a $12 \mathrm{hr}$ light/dark cycle with lights on at 6:00 A.M., with ambient temperature at $21 \pm 1^{\circ} \mathrm{C}$. Standard rat chow and water were available ad libitum until the beginning of the experiment. Body weight and fluid intake were measured daily between 8:00 A.M. and 9:00 A.M. throughout the experiment. All protocols used were performed in accordance with the NIH guidelines for the care and use of laboratory animals and were approved by the Institutional Animal Care and Use Committee.

\section{Experimental groups}

All rats were allowed $3 \mathrm{~d}$ to acclimate to their new surrounding before beginning the experiment (on day 4). For the induction of hyperosmolality by salt loading, rats were given $2 \% \mathrm{NaCl}$ solution as a sole source of their fluid intake for $72 \mathrm{hr}$. Rat chow was available ad libitum. For induction of hypo-osmolality, sustained hypo-osmolality was achieved by combined subcutaneous infusions of the VP analog 1-desamino-[8-D-arginine] vasopressin (dDAVP) (Peninsula Laboratories, Belmont, CA), using osmotic minipumps and ingestion of a nutritionally balanced liquid diet (Verbalis, 1984). Rats were acclimated for $3 \mathrm{~d}$ to a commercial balanced liquid diet (AIN-76; Bio-Serv, Frenchtown, $\mathrm{NJ}$ ) (the diet is modified to give $1.75 \mathrm{kcal} / \mathrm{ml}$ energy) using liquid feeding tubes at $\sim 50 \mathrm{ml} / \mathrm{d}$. After the equilibration period, an osmotic minipump (model 2002; Alzet, Palo Alto, CA) containing dDAVP, dissolved in $0.2 \mathrm{M}$ acetic acid at a concentration of $10 \mathrm{ng} / \mu \mathrm{l}$, was implanted subcutaneously along the back of the animal under methoxyflurane (Metofane) anesthesia. On the day of the insertion of minipumps, rats were given $70 \mathrm{ml}$ of a $1.16 \mathrm{kcal} / \mathrm{ml}$ formulation of liquid diet to rapidly induce hypoosmolality. On the next $2 \mathrm{~d}$, rats were given $50 \mathrm{ml}$ of modified liquid diet $(1.75 \mathrm{kcal} / \mathrm{ml})$ as a single morning feed. For iso-osmotic controls, for the hyper-osmotic group, control rats continued to have access ad libitum to tap water and rat chow throughout the experiment. For the hypoosmotic group, control rats received osmotic minipumps containing vehicle only and the liquid diet. The effectiveness of the hyper-osmolality and hypo-osmolality regimens was assessed by hematocrit and plasma osmolality (microvapor pressure osmometer; Wescor, Logan, UT) of trunk blood.

\section{In situ hybridization histochemistry}

Seventy-two hours after the start of experimentation, rats were decapitated between 9:00 A.M. and 12:00 P.M. Their brains were removed and snap frozen on powdered dried ice. At the time of decapitation, trunk blood was collected for determination of plasma VP, OT, $\mathrm{E}_{2}$, and $\mathrm{T}$ (see below). Coronal cryostat sections $(12 \mu \mathrm{m})$ were cut through the hypothalamus, thaw mounted onto poly-L-lysine- (Sigma, St. Louis, MO) coated microscope slides, and stored at $-80^{\circ} \mathrm{C}$ until use. Every fifth section was separately mounted and stained with Toluidine-Blue-O (Sigma) to locate regions of interest. The hybridization was performed as follows. Briefly, mounted sections were fixed in cold $4 \%$ paraformaldehyde, rinsed in $1 \times$ PBS, pH 7.4, immersed in $0.3 \%$ acetic anhydridetriethanolamine, and dehydrated through a graded series of ethanol solutions. Sections were then hybridized with the ${ }^{35}$ S-labeled antisense ER- $\beta$ riboprobe, a 400 bp AccI-EcoRI fragment encoding the $5^{\prime}$ untranslated region of rat ER- $\beta$ cDNA originally prepared by G. G. Kuiper (Karolinska Institute, Huddinge, Sweden). This region of the probe shares the least homology to other steroid hormone receptors. The probe was generated by in vitro transcription, in the presence of ${ }^{35} \mathrm{~S}$ UTP, with T3-RNA polymerase after plasmid linearization with EcoRI, mixed with $50 \%$ formamide in a humidified chamber at $50^{\circ} \mathrm{C}$ overnight. After the incubation, slides were washed in $2 \times \mathrm{SSC}$ at room temperature (RT) (three times for $5 \mathrm{~min}$ each), treated with $30 \mu \mathrm{g} / \mathrm{ml} \mathrm{RNaseA}$ (bovine pancreas; Sigma) at $37^{\circ} \mathrm{C}$ for $60 \mathrm{~min}$, and then rinsed with $2 \times \mathrm{SSC}$ at room temperature for $60 \mathrm{~min}$. Subsequently, slides were washed in $0.1 \times$ SSC at $60^{\circ} \mathrm{C}$ for $90 \mathrm{~min}$, followed by another wash starting at $60^{\circ} \mathrm{C}$, and then were allowed to cool to room temperature. Sections were dehydrated through a series of alcohols (50, 70, and 90\%) made by adding $100 \%$ ethanol to $0.3 \mathrm{~m}$ ammonium acetate solution. Slides were left to dry at room temperature then were apposed to Kodak Biomax MR (Amersham Biosciences, Piscataway, NJ), for 2 weeks. After apposition and development of the film, the slides were dipped in NTB2 liquid nuclear emulsion (diluted 1:1 with double distilled water; Eastman Kodak, Rochester, NY), exposed for 5 weeks, photographically processed, stained with $1 \%$ Pyronin-Y (Sigma), and coverslipped.

Specificity of the probes. In situ hybridization histochemistry (ISH) with sense probes were included in the experiment. A sense probe has an identical sequence to the cellular mRNA of interest and will not hybridize, so serving as a negative control. All ISHs with sense probes were conducted under identical conditions to those for antisense probes. Additionally, we also included tissue sections that were pretreated with RNaseA to eliminate mRNA from the tissue before hybridization with antisense riboprobes for ER- $\beta$ mRNA.

Quantification of ISH autoradiographs. Anatomical identification of brain structures was based on Paxinos and Watson stereotaxic rat brain atlases (Paxinos and Watson, 1986, 1996). Hybridization signals for ER- $\beta$ mRNA were evaluated by measuring optical density of digitized film images of the $\mathrm{SON}$ or by counting silver grains overlying the profiles of individual magnocellular neurons. Integrated optical density was measured for six to eight images of SON. Silver grains were counted on images of SON and PVN obtained with an AX70-Macro Research System Olympus MagnaFire Microscope (Olympus America, Melville, NY) using Scion (Frederick, MD) Image analysis system (Scion NIH Image for Windows, version Beta 4.0.2). Eight magnocellular neurons per section were counted in three to four sections per region per rat. Background measurements were made over appropriate adjacent tissue with no evident expressing neurons and subtracted to obtain the ER- $\beta$-specific silver grain counts. Analysis was performed blind to treatment. Animal means were calculated for each variable, and these values were used to calculate group means.

\section{Immunocytochemistry}

Seventy-two hours after $2 \% \mathrm{NaCl}$ ingestion in salt-loaded animals (hyper-osmotic; $n=6$ ) or water in controls (iso-osmotic; $n=6$ ), rats were anesthetized with Avertin and perfused transcardially with physiological saline, followed by $3.75 \%$ acrolein (EM Grade; Electron Microscopy Sciences, Fort Washington, PA) in phosphate-buffered $4 \%$ paraformaldehyde, pH 6.7 (Sigma). After fixation, brains were removed and allowed to sink in $30 \%$ aqueous sucrose for at least $48 \mathrm{hr}$. Cryostat brain slices, 30 - $\mu \mathrm{m}$-thick (starting rostrally at the level of medial preoptic area and ending caudally at lateral hypothalamic area), were collected in a 1-in-3 series and placed in culture wells with cryoprotectant solution $(30 \%$ sucrose and 30\% ethylene glycol in $0.1 \mathrm{M}$ PBS).

Single immunolabeling for $E R-\beta$. Cryoprotectant was removed from freely floating tissue sections with multiple rinses of $0.05 \mathrm{M}$ potassium PBS (KPBS), pH 7.4. Tissues were then treated with $1 \%$ sodium borohydride for $20 \mathrm{~min}$, followed by several rinses with KPBS. Sections were then incubated with $0.2 \%$ Triton X-100 (two times for 10 min each) and then $0.1 \mathrm{M}$ glycine for $30 \mathrm{~min}$. All solutions were prepared in KPBS, and multiple rinses with KPBS were used between each treatment. The sections were then incubated in blocking solution (20\% normal donkey serum, $1 \% \mathrm{BSA}$, and $1 \% \mathrm{H}_{2} \mathrm{O}_{2}$ in $\mathrm{KPBS}$ ) for $30 \mathrm{~min}$. All procedures were performed at RT. The tissues were then incubated in primary antibody with an affinity-purified rabbit polyclonal antiserum raised against amino acids $468-485$ of ER- $\beta$ (Z8P; Zymed, San Francisco, CA) at 1:5000 dilution made up in KPBS with $0.4 \%$ Triton X-100-1\% normal donkey serum for $60 \mathrm{~min}$ at RT and then $72 \mathrm{hr}$ at $4^{\circ} \mathrm{C}$. This antibody has been shown to recognize ER- $\beta$ but not ER- $\alpha$ protein, and its immunoreactivity (IR) colocalizes with ER- $\beta$ mRNA in the rat brain (Shughrue and Merchenthaler, 2001). The sections were rinsed with KPBS (10 times for $6 \mathrm{~min}$ each) and incubated with biotinylated donkey anti-rabbit serum (Jackson ImmunoResearch, West Grove, PA) at 1:600 in KPBS 
with $0.4 \%$ Triton X-100 for $1 \mathrm{hr} 15 \mathrm{~min}$ at RT. After several rinses, tissues were incubated in avidin-biotin complex solution for $1 \mathrm{hr} 15 \mathrm{~min}$ at RT (Vector Elite Kit; Vector Laboratories, Burlingame, CA) (with $50 \mu \mathrm{l}$ of avidin and $50 \mu \mathrm{l}$ of biotin in $10 \mathrm{ml}$ of KPBS with $0.4 \%$ Triton X-100). Tissues were rinsed in KPBS (three times for 5 min each), followed by three rinses for $5 \mathrm{~min}$ each in $0.175 \mathrm{M}$ sodium acetate. Primary antibody was localized using a conventional immunoperoxidase method with a 10 min exposure to nickel sulfate $(25 \mathrm{mg} / \mathrm{ml})$ plus diaminobenzidine- $\mathrm{HCl}$ (DAB) $(0.2 \mathrm{mg} / \mathrm{ml})$ in sodium acetate solution containing $0.83 \mu \mathrm{l}$ of $3 \%$ $\mathrm{H}_{2} \mathrm{O}_{2}$. This yielded a blue-black reaction product in the nuclear compartment. The sections were rinsed in sodium acetate (three times for 5 min each) and then three times for 5 min each in KPBS. Sections were mounted on poly-L-lysine-treated slides, air dried overnight, dehydrated in a series of graded alcohols, cleared in Histoclear (National Diagnostics, Atlanta, GA), and coverslipped with Protocol (Fisher Diagnostics, Middletown, VA). In the initial experiment, omission of the primary antibody or highly diluted concentrations resulted in the absence of immunoreactivity (data not shown).

Double immunolabeling for simultaneous detection of ER- $\beta$ and OT or $V P$. All procedures were conducted in an identical manner to the ER- $\beta$ single-labeling method, except that, after DAB-nickel intensified reaction, tissues were incubated for $60 \mathrm{~min}$ at RT and then for $48 \mathrm{hr}$ at $4^{\circ} \mathrm{C}$ in mouse monoclonal antibodies for either oxytocin-neurophysin (PS38) or vasopressin-neurophysin (PS41) at 1:2500 dilution [both antibodies were generously provided by Dr. Harold Gainer (National Institutes of Health, Bethesda, MD)] made up in KPBS with $0.4 \%$ Triton X-100. After the incubation period, tissues were rinsed with KPBS ( 10 times for $6 \mathrm{~min}$ each) and incubated with a biotinylated donkey anti-mouse serum (Jackson ImmunoResearch) at 1:600 in KPBS with $0.4 \%$ Triton X-100 for $1 \mathrm{hr}$ $15 \mathrm{~min}$ at RT. After rinsing, tissues were incubated in avidin-biotin complex solution for $1 \mathrm{hr} 15 \mathrm{~min}$ at RT (Vector Elite Kit with $50 \mu \mathrm{l}$ of avidin and $50 \mu \mathrm{l}$ of biotin in $10 \mathrm{ml}$ of KPBS with $0.4 \%$ Triton X-100) and then rinsed in KPBS (three times for 5 min each), followed by three rinses for 5 min each in $0.05 \mathrm{M}$ Tris buffer, $\mathrm{pH}$ 7.2. Staining was visualized using a non-nickel-intensified version of the immunoperoxidase procedure with $0.2 \mathrm{mg} / \mathrm{ml} \mathrm{DAB}$ in Tris buffer for $7 \mathrm{~min}$. This yielded a brown cytoplasmic reaction product. Tissues were rinsed three times for $5 \mathrm{~min}$ each in Tris buffer and then three times for 5 min each in KPBS. Sections were mounted from saline on poly-L-lysine-treated slides, air dried overnight, dehydrated in a series of graded alcohols, cleared in Histoclear (National Diagnostics), and coverslipped with Protocol (Fisher Diagnostics).

Double immunolabeling for simultaneous detection of FOS and OT. A similar double immunolabeling procedure as above was used, except that the ER- $\beta$ antibody was replaced with a rabbit affinity-purified polyclonal antibody against c-FOS (sc-253; Santa Cruz Biotechnology, Santa Cruz, CA) at 1:75,000 dilution in KPBS with $0.4 \%$ Triton X-100 without normal serum. Sections were incubated for $60 \mathrm{~min}$ at RT and then for $72 \mathrm{hr}$ at $4^{\circ} \mathrm{C}$.

Quantification of ER- $\beta$ immunoreactivity. ER- $\beta$ and FOS are primarily localized in the nucleus and thus stained as blue-black immunoprecipitants in the nuclear compartment of the cells after DAB-nickel reaction, whereas VP and OT stains yield brown cytoplasmic deposits with DAB alone. For double-labeling experiments, positive cells were identified as those expressing both black nuclear and brown cytoplasmic reaction products. Cell counts were performed manually on images obtained with an AX70-Macro Research System Olympus MagnaFire Microscope (Olympus America). Analysis was performed blind to treatment at the time of evaluation. Animal means were calculated for each variable, and these values were used to calculate group means.

\section{Radioimmunoassays}

Trunk blood was collected at the time of decapitation in lithiumheparin-treated microtubes, and cells were removed by centrifugation. Plasma was aliquoted in appropriate amounts for subsequent hormone measurements to avoid repeated freeze-thaw cycles. Plasma VP and OT concentrations were measured using antisera from Arnel Products (Brooklyn, NY) at a final dilution of 1:150,000 and 1:100,000, respectively, after ether-acetone extraction as described previously (Catudioc-
Table 1. Effect of $72 \mathrm{hr}$ of $2 \%$ hypertonic saline ingestion (Hyper-) and induced hypo-osmolality (Hypo-) on mean \pm SEM body weight, plasma osmolality, hematocrit, and plasma hormone concentrations

\begin{tabular}{lccc}
\hline & Hyper- $(n=6)$ & Iso- $(n=6)$ & Hypo- $(n=6)$ \\
\hline Body weight $(\mathrm{g})$ & & & \\
$\quad$ Day 1 & $290.1 \pm 7.1$ & $282.6 \pm 4.2$ & $278.6 \pm 4.9$ \\
Day 4 & $313.4 \pm 8.4$ & $297.5 \pm 9.1$ & $286.8 \pm 5.5$ \\
$\quad$ Day 4 $+72 \mathrm{hr}$ & $296.5 \pm 10.4$ & $317.2 \pm 13.6$ & $295.2 \pm 7.3$ \\
Plasma 0smolality $\left(\mathrm{m0sm} / \mathrm{kg} \mathrm{H}_{2} 0\right)$ & $312.8 \pm 6.4^{*}$ & $295.5 \pm 0.8^{*}$ & $219.0 \pm 4.7^{*}$ \\
Hematocrit $(\%)$ & $45.1 \pm 1.1^{* *}$ & $41.2 \pm 0.5^{* *}$ & $42.9 \pm 0.9$ \\
Plasma VP (pg/ml) & $4.2 \pm 1.2$ & U.D. & $\mathrm{N} / \mathrm{A}$ \\
Plasma 0T (pg/ml) & $25.5 \pm 2.3^{* * *}$ & $15.7 \pm 0.7$ & $17.1 \pm 1.9$ \\
Plasma T $(\mathrm{ng} / \mathrm{ml})$ & $0.5 \pm 0.1$ & $3.3 \pm 0.6^{* * *}$ & $0.3 \pm 0.1$ \\
Plasma $\mathrm{E}_{2}(\mathrm{pg} / \mathrm{ml})$ & $5.0 \pm 0.4$ & $3.5 \pm 0.6$ & $2.9 \pm 0.7$ \\
\hline
\end{tabular}

$\mathrm{N} / \mathrm{A}$, Data not available because of dDAVP cross-reactivity in the VP RIA; U.D., undetectable (detection limit, 1.0 $\mathrm{pg} / \mathrm{ml})$.

${ }^{*} p<0.05$ from each other; ${ }^{* *} p<0.05$ versus each other; ${ }^{* * *} p<0.05$ versus the other two groups.

Vallero et al., 2000). The buffer used for both assays was $0.1 \mathrm{~m} \mathrm{PBS,} \mathrm{pH}$ 7.6, with $1 \mathrm{mg} / \mathrm{ml}$ bovine serum albumin and $1 \mathrm{mg} / \mathrm{ml}$ sodium azide. Non-equilibrium incubation conditions were used for the VP RIA. Both standards and samples were incubated for $24 \mathrm{hr}$ at $4{ }^{\circ} \mathrm{C}$ with VP antiserum, followed by an additional $72 \mathrm{hr}$ incubation in the presence of 2000 cpm of ${ }^{125} \mathrm{I}$-arginine vasopressin $\left({ }^{125} \mathrm{I}-\mathrm{VP}\right)$ (PerkinElmer Life Sciences, Boston, MA). For the OT RIA, both standards and samples were incubated for $96 \mathrm{hr}$ at $4^{\circ} \mathrm{C}$ with antibody and $3500 \mathrm{cpm}$ of ${ }^{125} \mathrm{I}$-oxytocin $\left({ }^{125} \mathrm{I}\right.$-OT) (PerkinElmer Life Sciences). Antibody-bound VP or OT was separated from free peptide with dextran-coated charcoal, and the amount of ${ }^{125} \mathrm{I}-\mathrm{VP}$ or ${ }^{125} \mathrm{I}-\mathrm{OT}$ in the pellet was determined with a gamma counter. The minimum sensitivity for the VP assay was $0.1 \mathrm{pg} /$ tube, whereas that of OT was $1.0 \mathrm{pg} /$ tube. After correction for extraction recovery and assay of $200 \mu \mathrm{l}$ of extracted plasma, this yielded a minimum detection limit of 1 and $5 \mathrm{pg} / \mathrm{ml}$ plasma for the VP and OT RIAs, respectively. Total $\mathrm{T}$ and $\mathrm{E}_{2}$ concentrations were determined by the doubleantibody method using commercially available kits according to the protocols of the manufacturer (Diagnostic Systems Laboratories, Webster, TX). The minimum sensitivity of the assays were $0.05 \mathrm{ng} / \mathrm{ml}$ and 2.20 $\mathrm{pg} / \mathrm{ml}$ for $\mathrm{T}$ and $\mathrm{E}_{2}$, respectively. The intra-assay and inter-assay coefficients of variation were 7.5 and $8.1 \%$ for $\mathrm{T}$ and 7.48 and $9.35 \%$ for $\mathrm{E}_{2}$, respectively.

\section{Statistical analysis}

Student's $t$ test or one-way ANOVA (or Kruskal-Wallis analysis on ranks), with post hoc Student-Newman-Keuls tests were used (SigmaStat software; SPSS, Chicago, IL), as appropriate, to compare groups. $p<0.05$ was considered statistically significant. Results are expressed as the group means \pm SEM.

\section{Results}

Body weight, plasma osmolality, hematocrit, and plasma hormone concentrations in hyper-osmotic, iso-osmotic, and hypo-osmotic animals

Table 1 and Figure 1 present data from the animals used for the in situ hybridization study. Because there were no significant differences between the iso-osmotic control groups for the hyperosmolality and hypo-osmolality protocols, the data from the two control groups were combined, and ANOVA was performed to assess differences between the hyper-osmotic, iso-osmotic, and hypo-osmotic groups. There was no significant difference in the initial body weight or in the rate of weight gain during the acclimation period in the three groups of animals (day $1, F=1.11, p=$ 0.34 ; day $4, F=2.95, p=0.08$ ). Although body weight continued to increase in the iso-osmotic controls during the experiment, it gradually declined in the hyper-osmotic and hypo-osmotic animals, although this was not statistically different $(F=2.32, p=$ 0.298) (Fig. 1). A similar decline in body weight was observed in 


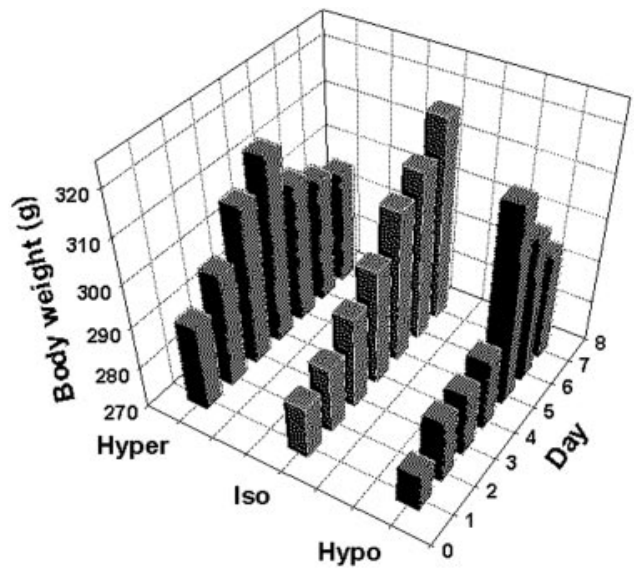

Figure 1. Change in body weight in the hyper-osmolality, iso-osmolality, and hypoosmolality groups during the acclimation and experimental periods.

rats that were subjected to hypertonic saline ingestion in the ER- $\beta$ immunolabeling study (data not shown). Plasma osmolality significantly increased during salt loading, whereas there was a dramatic decrease in this parameter in the hypo-osmotic animals (Kruskal-Wallis analysis on ranks; $p<0.001$ ). This supports the efficacy of the protocols for induction of hyper-osmolality and hypo-osmolality. Hematocrit was slightly but significantly increased in the hyper-osmotic group $(F=4.90, p=0.023)$, suggesting the possibility that a slight plasma volume deficit occurred in these animals in addition to increased osmolality. Both plasma VP and OT were significantly increased after salt loading. Plasma OT was not different between iso-osmotic and hypoosmotic groups. Plasma VP was $<1.0 \mathrm{pg} / \mathrm{ml}$ in the iso-osmotic group. Cross-reactivity of dDAVP in the assay prevented an accurate determination of plasma VP concentration in the hypoosmotic group.

\section{Changes in ER- $\boldsymbol{\beta}$ mRNA expression in magnocellular neurons} after altered plasma osmolality

The specificity of ER- $\beta$ mRNA labeling was verified using sections that were either hybridized with sense probes or subjected to RNase pretreatment. Hybridization signal was undetectable with sense probes (Fig. 2) or with RNase pretreatment (data not shown). Additionally, the pattern of distribution of ER- $\beta$ mRNA obtained with this probe was comparable with that reported previously (Osterlund et al., 1998) and was distinct from that of ER- $\alpha$.

Chronic hyper-osmolality or hypo-osmolality induced significant changes in the expression of ER- $\beta$ mRNA in MNCs that were inversely correlated with changes in plasma osmolality. Thus, the expression of ER- $\beta$ mRNA was decreased by chronic hyper-osmolality and increased by chronic hypo-osmolality (Fig. $3)$. In the SON, hyper-osmolality reduced the number of ER- $\beta$ specific silver grains per neuron to $30 \%(p<0.05)$ of the values in iso-osmotic controls, whereas there was a $46 \%$ increase $(p<$ 0.05 ) in the number of grains per neuron in response to sustained hypo-osmolality (Kruskal-Wallis analysis on ranks; $p=0.002$ ) (Fig. 4A). Similarly, hyper-osmolality induced a 36\% decrease and hypo-osmolality a $22 \%$ increase $(p<0.009)$ in the relative optical density of ER- $\beta$ mRNA expression over the SON proper by film measurement $(F=34.98, p<0.001)$ (Fig. $4 B)$. Together, these measurements indicate altered ER- $\beta$ mRNA expression within individual as well as across the populations of neurons in the SON.
Changes in ER- $\boldsymbol{\beta}$ immunoreactivity in magnocellular neurons with hypertonic saline ingestion

Immunocytochemistry was also used to evaluate ER- $\beta$ expression to determine whether the changes in ER- $\beta$ mRNA were translated into changes in receptor protein content in MNCs. ER- $\beta$-IR was found to correspond to its mRNA expression. Thus, in iso-osmotic rats, numerous intense ER- $\beta$-IR neurons were found throughout the rostrocaudal extent of SON (Fig. $5 A$ ) and posterior magnocellular PVN (Fig. 5G). Chronic hyperosmolality virtually eliminated ER- $\beta$-IR from SON and magnocellular PVN (Fig. $5 B, H$ ), indicating that the decrease in ER- $\beta$ mRNA observed with $72 \mathrm{hr}$ of salt loading was reflected in a decrease in receptor protein.

\section{ER- $\boldsymbol{\beta}$ colocalization in VP magnocellular neurons}

ER- $\beta$-IR was localized primarily in the ventral region of the SON (Fig. 5A). This region contains predominantly VP-immunoreactive neurons. Similarly, in PVN, ER- $\beta$-IR is dense in the interior portion of the posterior magnocellular area, which also contains primarily VP MNCs (Fig. 5G). Indeed, by using a double-immunolabeling method, ER- $\beta$ was found to only occasionally colocalize with OT in the SON ( $\sim 7.5 \%)$ (Fig. $5 C$ ) and magnocellular PVN (Fig. 5I), suggesting that ER- $\beta$ is principally expressed in the VP MNCs in these regions. This was confirmed in sections from iso-osmotic rats double labeled for VPneurophysin and ER- $\beta$ (Fig. 6C,G). This finding is in good agreement with many previous reports (Alves et al., 1998; Hrabovszky et al., 1998). The low expression of ER- $\beta$ in OT MNCs was also observed in the accessory nuclei, including nucleus circularis (Fig. $6 H$ ).

\section{ER- $\boldsymbol{\beta}$ expression in PVN: selective effect of osmolality on MNCs}

One of the areas that exhibits ER- $\beta$ expression most strongly in rat brain is PVN. The PVN is an important integrating site for behavioral, neuroendocrine, and autonomic responses to various stimuli (Swanson and Sawchenko, 1983; Liposits, 1993). These physiological responses are mediated by distinct subsets of intricately organized neurons found in this nucleus. In contrast to SON, PVN is comprised of two types of neurons: (1) magnocellular neurons, which produce VP and OT, project to neurohypophysis, and function similarly to the magnocellular neurons found in SON; and (2) parvocellular neurons, which perform varied and distinct neuroendocrine and autonomic functions and are regulated differently from magnocellular neurons (Swanson and Kuypers, 1980; Sawchenko et al., 1996; Viau and Sawchenko, 2002). Functionally, neurons within the PVN can be broadly classified into three groups: those that project to the posterior pituitary [posterior magnocellular neurons $(\mathrm{pm})]$, those that project to the median eminence [hypophysiotrophic medial parvocellular neurons, dorsal part ( $\mathrm{mpd}$ )] and the visceromotor cell group, which projects to the autonomic nervous system [including dorsal parvocellular (dp) and medial parvocellular neurons, ventral part (mpv)] (Fig. 6E). As shown in Figures 5-7, ER- $\beta$-IR is exhibited throughout the PVN proper under basal condition. Its expression is found most strongly in regions that project to the autonomic regulatory centers in brainstem and spinal cord (particularly mpv) and posterior pituitary ( $\mathrm{pm})$, with much lower expression in areas that project to the median eminence $(\mathrm{mpd})$. Interestingly, only ER- $\beta$-IR in pm disappeared with chronic hyper-osmolality, whereas its expression in other compartments of PVN was preserved (Fig. $5 \mathrm{H}, \mathrm{J}$ ). A large proportion of these parvocellular neurons are also reactive for OT 

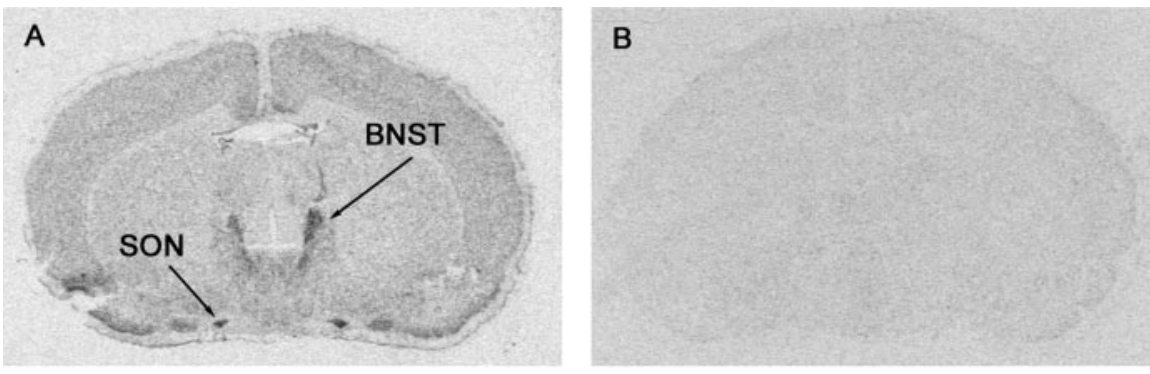

Figure 2. Representative photomicrographs from in situ hybridization histochemistry of $12-\mu \mathrm{m}$-thick coronal rat brain sections. $A$, Autoradiogram of tissue section hybridized with ${ }^{35}$ S-labeled antisense riboprobe for ER- $\beta$ mRNA. Note the specific hybridization signals for ER- $\beta$ mRNA in the bed nucleus of the stria terminalis (BNST) and SON. B, Autoradiogram of anatomically comparable section hybridized with ${ }^{35}$ S-labeled sense-riboprobe for ER- $\beta$ mRNA. No hybridization signal was observed in sections incubated with $E R-\beta$ sense probes, confirming the specificity of the antisense hybridization.
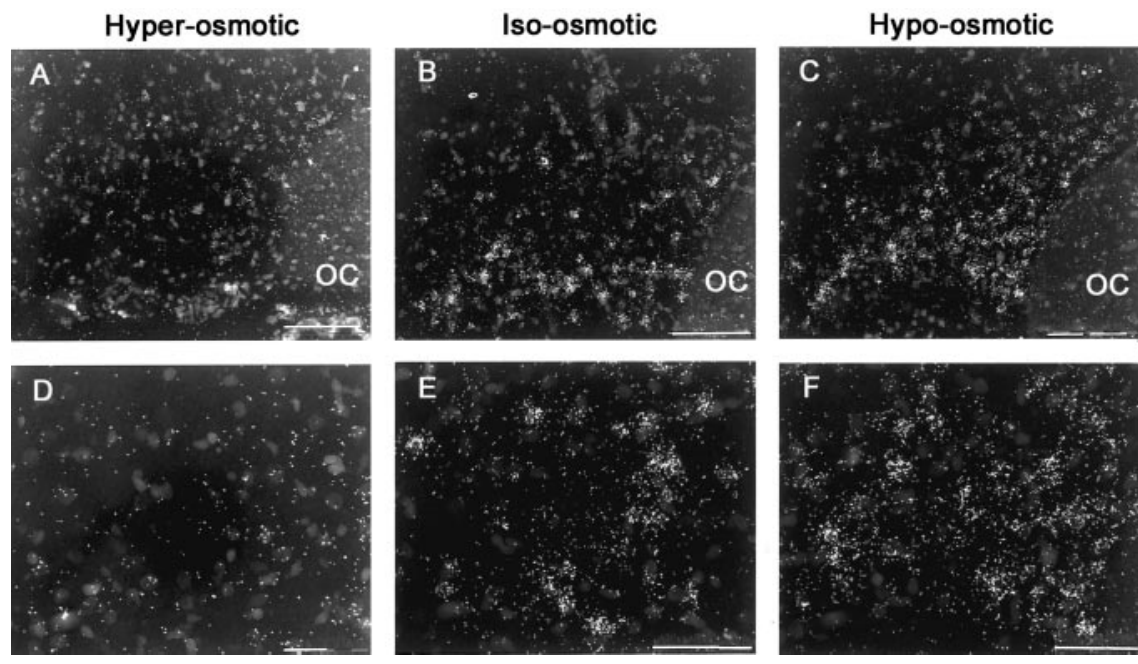

Figure 3. Representative photomicrographs from in situ hybridization histochemistry of $12-\mu \mathrm{m}$-thick, emulsion-dipped coronal rat brain sections. $A-C$ are dark-field micrographs of anatomically comparable sections through $S O \mathrm{~N}$ hybridized with ${ }^{35} \mathrm{~S}$ labeled antisense riboprobe for ER- $\beta$ mRNA from hyper-osmotic, iso-osmotic, and hypo-osmotic rats, respectively. $D-F$ are dark-field, high-magnification micrographs of magnocellular supraoptic neurons from hyper-osmotic, iso-osmotic, and hypoosmotic rats, respectively. Scale bars: $A-C, 100 \mu \mathrm{m} ; D-F, 50 \mu \mathrm{m}$. OC, Optic chiasm.

(and to a lesser extent for VP). Thus, in sections that were double labeled for ER- $\beta$ and OT, the number of parvocellular ER- $\beta$ immuno-reactive neurons that are also reactive for OT did not appear to be reduced by hyper-osmolality (Fig. 5, I for control, $J$ for hyper-osmolality).

This finding is also apparent more caudally in the lateral parvocellular (LP) part of PVN (Fig. 7). The ER- $\beta$-immunoreactive cells in this posterior region extensively colocalized with OT (Fig. 7A), with minimal labeling for VP (Fig. 7G). As illustrated in Figure $7 A-D$, ER- $\beta$-IR in these OT-expressing neurons remained unchanged in the hyper-osmolality group. Thus, there were $\sim 133 \pm 11$ LP neurons in iso-osmotic controls and $126 \pm 7$ neurons in hyper-osmotic animals that are ER- $\beta$-immunoreactive (Student's $t$ test; $p=0.61$ ), with colocalization of $48.96 \pm$ 1.93 and $51.04 \pm 1.19 \%$, respectively (Student's $t$ test; $p=0.45$ ).

\section{Activity-dependent regulation of ER- $\boldsymbol{\beta}$ immunoreactivity}

An immediate early gene, $c$-fos, has been extensively used immunocytochemically to identify neurons that are activated during application of specific stimuli (Hoffman and Lyo, 2002). VP and OT neurons are exquisitely sensitive to changes in plasma osmolality and exhibit robust expression of FOS-IR after increased osmolality. Given that the decrease in ER- $\beta$-IR after increased osmolality is selective for MNCs, it is conceivable that its expression might relate to the state of neuron activity. Thus, using FOS as a marker for neuronal activity, we examined the expression of FOS-IR in areas that express ER- $\beta$-IR in sections adjacent to those stained for ER- $\beta$ alone or ER- $\beta$ coupled with OT. In the iso-osmotic condition, there was little expression of FOS-IR in magnocellular SON and PVN (Fig. $5 E, K$ ). After a prolonged state of hyper-osmolality, however, FOS-IR was strongly induced in these neurons (Fig. $5 F, L)$. Thus, FOS expression is inversely correlated with ER- $\beta$ expression in MNCs. However, in the LP part of PVN, FOS-IR expression was not induced by hyperosmolality. Thus, there was minimal expression of FOS in both iso-osmotic controls and hyper-osmotic animals (Fig. $7 E, F)$. This is the area in which ER- $\beta$-IR remained unaltered by hyper-osmolality. Thus, ER- $\beta$ expression is downregulated in osmotically stimulated neurons but not in neurons unresponsive to osmotic stimulation.

\section{Regulation of ER- $\beta$ expression: circulating hormones}

Although the expression of ER- $\beta$ mRNA observed in this study is inversely correlated with plasma osmolality, it is possible that other mechanisms might be governing its expression. One likely candidate is the circulating gonadal steroids themselves. Therefore, circulating steroid concentrations were determined. Both plasma $\mathrm{E}_{2}$ and $\mathrm{T}$ were measured because $\mathrm{T}$ is regarded as a precursor for estrogen in the male brain (Lephart, 1996). There was a large suppression in $\mathrm{T}$ level after both hyperosmolality and hypo-osmolality $(F=16.85, p<0.001)$, whereas the concentration of $\mathrm{E}_{2}$ did not change significantly $(F=3.52$, $p=0.06$ ) (Table 1). Thus, the changes in ER- $\beta$ mRNA expression were not correlated with changes in either circulating $\mathrm{T}$ or $\mathrm{E}_{2}$. This suggests that the circulating hormones are not responsible for the changes in ER- $\beta$ mRNA expression observed in this study.

\section{Discussion}

Although $\mathrm{E}_{2}$ is generally regarded as a sex steroid hormone, a growing body of evidence suggests roles of $\mathrm{E}_{2}$ beyond those associated directly with reproduction. This is reflected by the extensive expression of both ER- $\alpha$ and ER- $\beta$ in structures that are not typically involved in reproductive physiology, including hypothalamic nuclei involved in fluid homeostasis and autonomic function. The impact of osmotic perturbations on ER- $\beta$ expression in SON and PVN was investigated to examine the significance of ER- $\beta$ expression in these nuclei and thereby the role of gonadal steroids in regulation of VP and OT secretion.

We found that the expression of ER- $\beta$ in MNCs is negatively correlated with changes in plasma osmolality. Plasma osmolality is one of the most important regulators of VP secretion with small increases in osmolality inducing VP release and its gene tran- 

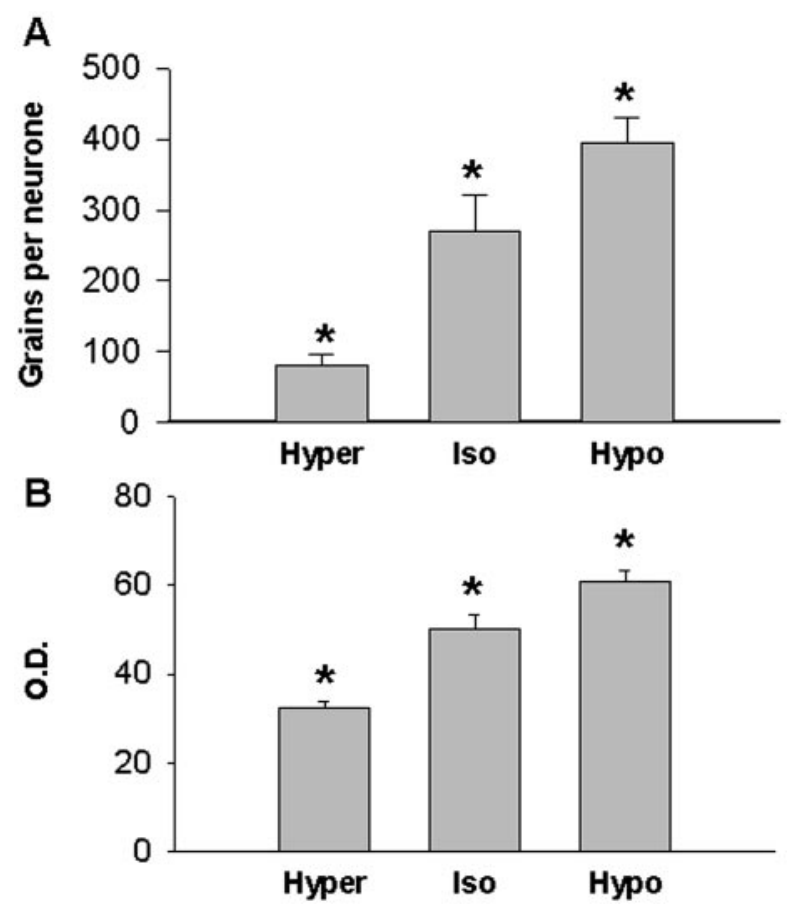

Figure 4. Expression of ER- $\beta$ mRNA in rat magnocellular supraoptic neurons after $72 \mathrm{hr}$ of $2 \%$ hypertonic saline ingestion (Hyper) and sustained hypo-osmolality (Hypo). A, Group mean \pm SEM specific silver grain counts per neuron from emulsion-dipped sections. $B$, Group mean \pm SEM relative optical density from film autoradiograms. $A,{ }^{*} p<0.05$ versus each other (Kruskal-Wallis ANOVA on ranks, followed by Student-Newman-Keuls post hoc test). $B,{ }^{*} p<$ 0.009 versus each other (one-way ANOVA, followed by Student-Newman-Keuls post hoc test).

scription and synthesis. Therefore, this finding is consistent with an inhibitory role for ER- $\beta$-mediated effects of $E_{2}$ on VP synthesis and release. In fact, we demonstrated previously inhibition of osmotically and NMDA-stimulated VP release in HNS explants by both $\mathrm{E}_{2}$ and $\mathrm{T}$ (Swenson and Sladek, 1997; Swenson et al., 1998), and we found that $E_{2}$ inhibition of NMDA-stimulated VP release is blocked by an antagonist of ER- $\beta$ (Somponpun and Sladek, 2002). Thus, downregulation of ER- $\beta$ expression during chronic hyper-osmolality would remove this inhibitory influence, allowing augmented VP secretion. Conversely, upregulation of ER- $\beta$ expression during chronic hypo-osmolality would contribute to inhibition of VP secretion, thereby allowing for maximal diuresis.

ER- $\beta$ protein is primarily localized in the nucleus of MNCs. This suggests that it functions as a transcription factor and that its inhibitory effects require altered gene expression. ERs classically alter gene expression by interaction with the estrogen response element (ERE) in the promoter region of genes, but they can also alter gene expression by interacting with other transcription factor protein complexes such as FOS/JUN complexes that bind to AP1 DNA sites (Kushner et al., 2000) and Sp1 complexes (Safe, 2001). Both VP and OT gene promoters contain elements with the potential for $\mathrm{E}_{2}$ regulation. Upstream regulatory regions for the VP gene include two ERE elements located $>4.0 \mathrm{~kb}$ upstream from the transcription start site (Shapiro et al., 2000). However, ER- $\beta$ influences VP gene expression by non-ERE-mediated mechanisms located within $1.1 \mathrm{~kb}$ of the start site. In this region, ER- $\beta$ constitutively enhances VP promoter activity in a receptor concentration-dependent manner and inhibits promoter activity in an $\mathrm{E}_{2}$-dependent manner (Shapiro et al., 2000). The regulatory sequences of the OT gene include a composite hormone response element, similar to an ERE at $-160 \mathrm{~kb}$ (for review, see Burbach et al., 1998). Although it allows binding of $\mathrm{E}_{2}$, it has a higher affinity for several orphan nuclear receptors, and $\mathrm{E}_{2}$ responsiveness has only been demonstrated in transfection systems that overexpress either ER- $\alpha$ or $-\beta$ (Stedronsky et al., 2002). Thus, ER- $\beta$ regulation of either VP or OT gene expression is likely to occur through protein complex interactions rather than direct actions at DNA response elements.

Although the VP and OT genes are prime candidates for regulation to influence hormone secretion, other genes could also be responsible for the inhibitory effects of ER- $\beta$ on peptide secretion. For example, neurotransmitter receptors are involved in the relay of osmotic information to VP and OT neurons. Osmotic stimulation of VP and OT release is dependent on glutamatergic transmission from neurons in organum vasculosum of the lamina terminalis (Russell et al., 1989; Hamamura et al., 1992). Previous experiments using HNS explants demonstrated that the glutamate receptor agonist NMDA evokes VP secretion, whereas its antagonists significantly inhibit osmotically stimulated VP release (Swenson et al., 1998). Furthermore, gonadal steroids including $\mathrm{E}_{2}$ inhibit NMDA-induced increases in VP release, and this inhibitory effect of $E_{2}$ is likely mediated via an ER- $\beta$ mechanism (Somponpun and Sladek, 2002). Certain NMDA receptor (NR) subunits are regulated in MNCs by osmotic stimulation. Functional NRs consist of coassembled NR1 and NR2 subunits, and SON neurons express NR1 and NR2B, NR2C, and NR2D subunits (Al-Ghoul et al., 1997). Osmotic stimulation enhances NR1 expression and likely alters the ratio of NR2 subunit expression (Decavel and Curras, 1997). The promoter regions of the NR1 and NR2C subunits contain functional SP1 sites (Bai and Kusiak, 1993; Klein et al., 1998). E $_{2}$ acts as a transcription repressor via ER- $\beta /$ SP1 complexes (Safe, 2001). Therefore, inhibition of NR subunit synthesis by ER- $\beta / \mathrm{SP} 1$ complexes could be responsible for the inhibitory effect of $E_{2}$ on NMDA-stimulated and osmotically stimulated VP release.

The predominant colocalization of ER- $\beta$ with VP rather than OT in SON and magnocellular PVN of control animals suggests that the influence of $\mathrm{E}_{2}$ (or other ligands) acting via $\mathrm{ER}-\beta$ would be more pronounced on VP than OT secretion under iso-osmotic conditions. However, genistein, a phytoestrogen, used at a concentration that selectively activates ER- $\beta$ prevented NMDAinduced release of both VP and OT from HNS explants (Somponpun and Sladek, 2002). This could reflect ER- $\beta$ expression in OT MNCs that is below the detection limit of the immunocytochemistry technique or it could reflect multiple mechanisms of actions of the steroids. The latter was also suggested by our earlier finding that $\mathrm{T}$ and $\mathrm{E}_{2}$ decreased both osmotically stimulated hormone release and induction of $\mathrm{mRNA}$, whereas dihydrotestosterone (DHT), a non-aromatizable androgen, prevented osmotically stimulated release of VP but did not prevent the increase in VP mRNA (Swenson and Sladek, 1997). Certain androgenic metabolites such as $5 \alpha$-androstane-3 $\alpha, 17-\beta$-diol, which can be derived from DHT (Shaw et al., 2000), has an affinity for ER- $\beta$ (Kuiper et al., 1996).

Although differential effects of $\mathrm{E}_{2}$ on VP and OT release might be expected in control animals, the observed changes in ER- $\beta$ expression after chronic hyper-osmolality and hypo-osmolality may minimize this disparity. The attenuation of ER- $\beta$ expression in VP neurons by hyper-osmolality rendered VP as well as OT neurons essentially devoid of functional ER. Thus, the impact of ER- $\beta$-mediated inhibition should be minimized in both VP and OT neurons by hyper-osmolality. After chronic hypo-osmolality, ER- $\beta$ mRNA expression is increased in the dorsal as well as ven- 

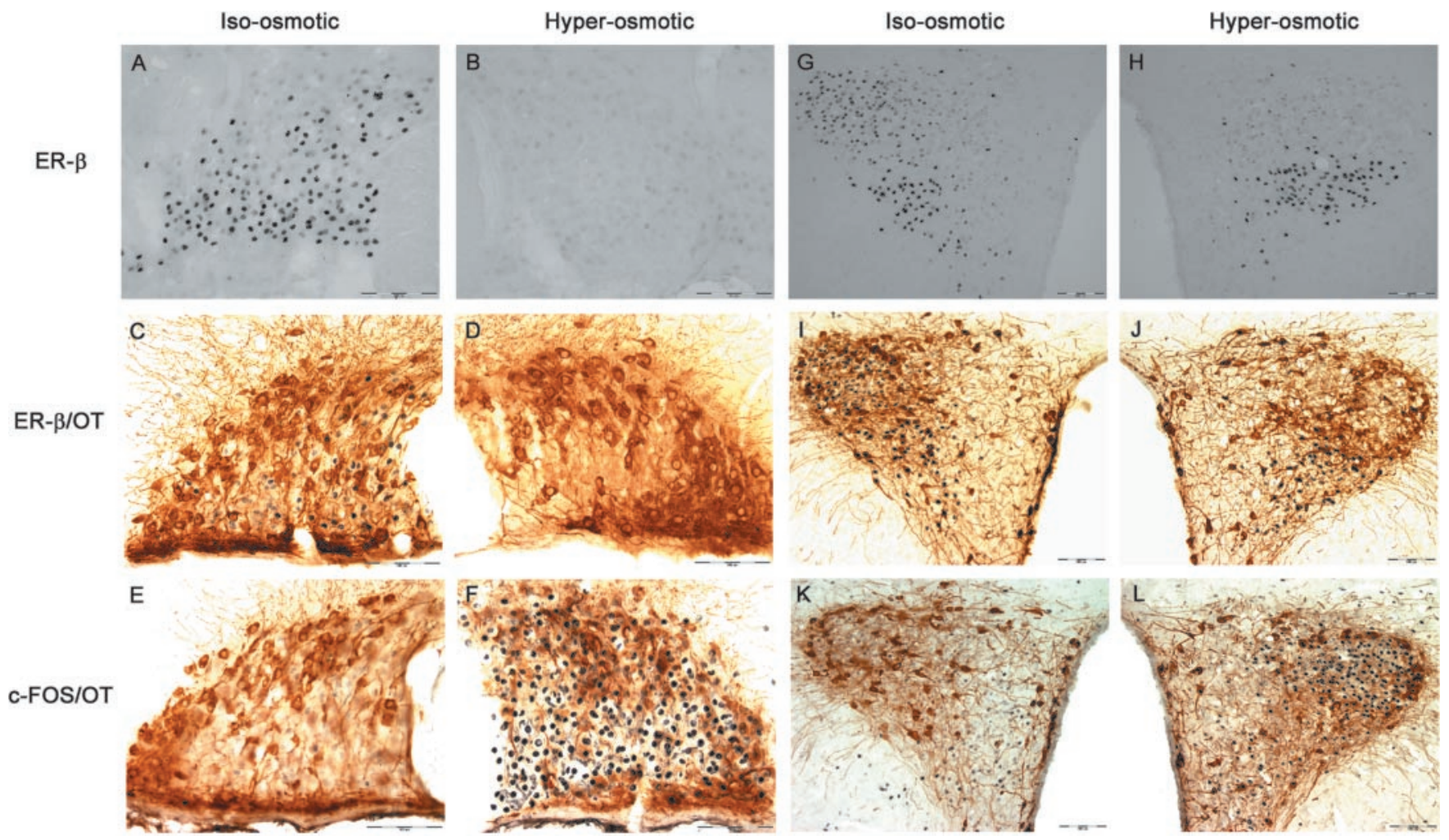

Figure 5. Photomicrographs of SON ( $A-F$ ) and PVN ( $G-L$ ) stained immunocytochemically for ER- $\beta$ alone (top row), ER- $\beta$ with oxytocin-neurophysin (OT) (middle row) or FOS with OT (bottom row) from iso-osmotic control rats (iso-osmotic) compared with rats that received $2 \%$ hypertonic saline ingestion (hyper-osmotic) for $72 \mathrm{hr}$. All three staining procedures were performed on adjacent sections, and the representative micrographs depict sections derived from the same rat. Scale bar, $100 \mu \mathrm{m} .0 \mathrm{C}$, Optic chiasm; 3V, third ventricle.
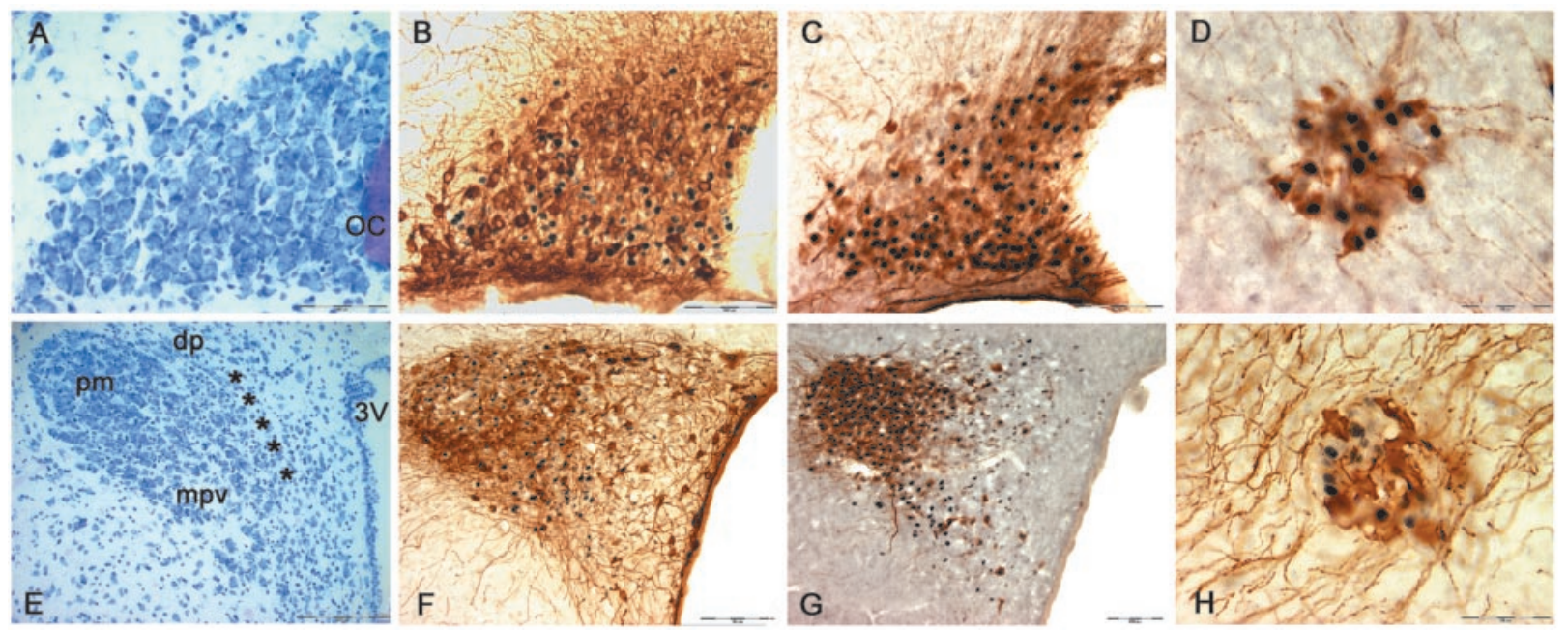

Figure 6. Photomicrographs of SON $(A-C), \operatorname{PVN}(E-G)$, and nucleus circularis $(D, H)$ from iso-osmotic control rats. $A$ and $E$ are Toluidine-Blue-0-stained sections through supraoptic and paraventricular nucleus. Whereas the SON contains essentially only magnocellular neurons $(A)$, the PVN represents a much more heterogeneous population of cells, comprising MNCs in the pm and diverse groups of parvocellular neurons parceled into the $\mathrm{dp}, \mathrm{mpv}$, and $\mathrm{mpd}\left({ }^{* * *}\right)$ regions of the nucleus $(E) . B, F$, Sections stained immunocytochemically for nuclear ER- $\beta$ followed by cytoplasmic oxytocin-neurophysin (OT). C, G, Anatomically comparable sections stained immunocytochemically for ER- $\beta$ followed by vasopressin-neurophysin (VP). Note that a greater proportion of ER- $\beta$-immunoreactive neurons are colocalized with VP rather than OT in supraoptic and magnocellular paraventricular neurons. The minimal colocalization between ER- $\beta$-IR and $0 T-I R$ is also observed in many accessory cell groups, including the nucleus circularis $(H)$, whereas ER- $\beta$-IR is coexpressed with VP-IR in this nucleus ( $D$ ). Scale bars: $A-C, F, G, 100 \mu \mathrm{m} ; D, H, 50 \mu \mathrm{m} ; E, 200 \mu \mathrm{m}$. OC, Optic chiasm; $3 \mathrm{~V}$, third ventricle.

tral regions of SON. Because OT neurons are predominantly located in the dorsal region (compare Fig. $5 C-F$ with Fig. $3 C$ ), chronic hypo-osmolality may induce ER- $\beta$ in OT MNCs. Although additional work is required to verify this, it would be consistent with the need to suppress the natriuretic actions of OT (Verbalis et al., 1991) under conditions of chronic hyponatremia.
Although ER- $\beta$ is predominantly expressed in VP rather than OT MNCs, the reverse is found in the parvocellular compartments of PVN. In agreement with several other reports (Alves et al., 1998; Hrabovszky et al., 1998), prominent ER- $\beta$ expression was apparent in mpv parvocellular neurons at the same rostrocaudal level as the MNCs (Fig. 5) as well as more caudally at 
lateral PVN (Fig. 7). Many of these cells coexpressed OT, whereas few contained detectable VP. However, because numerous VP mRNA-expressing neurons exists in the lateral parvocellular region of PVN (Hallbeck and Blomqvist, 1999; Hallbeck et al., 1999), the apparent difference between OT and VP colocalization with ER- $\beta$ may reflect low VP peptide content in the absence of colchicine treatment. ER- $\beta$ expression was preserved in these regions after saline consumption. This is consistent with the well recognized differential roles of the parvocellular versus magnocellular populations in PVN. Whereas the MNCs predominantly send axons to neural lobe and release VP and OT into the peripheral circulation, the parvocellular regions project to either autonomic regulatory centers in the brainstem and spinal cord or the median eminence for regulation of anterior pituitary hormone release. Similarly, afferent pathways to the parvocellular neurons are distinct from the MNCs, again, reflecting their functional diversity. The absence of hyper-osmolality-induced FOS expression in the parvocellular neurons is consistent with the absence of osmo-excitatory afferents to these cells.

In terms of mechanisms regulating ER- $\beta$ expression, two possible signals were considered in this study. (1) As described above, FOS induction was negatively correlated with ER- $\beta$ expression in SON and PVN MNCs, and the decrease in ER- $\beta$ was only observed in activated neurons. Thus, one possibility is that neuronal activation downregulates ER- $\beta$ expression. Selective activation of the parvocellular populations expressing ER- $\beta$ would be useful to substantiate this hypothesis. (2) $\mathrm{E}_{2}$ has been shown to regulate ER- $\beta$ mRNA expression in rat PVN (Patisaul et al., 1999, 2001) and to decrease ER- $\beta$ immunoreactivity in mouse PVN (Nomura et al., 2003). How-

ever, in this study, there was no correlation between plasma $\mathrm{T}$ nor $\mathrm{E}_{2}$ with $\mathrm{ER}-\beta$ expression in MNCs with osmotic manipulation. Therefore, the observed changes in ER- $\beta$ expression were not governed by changes in circulating steroids. The selective change in ER- $\beta$ expression only in MNCs further supports this conclusion. However, because the endogenous ligand for these receptors and its source remains to be established, it is still possible that the receptor is regulated by changes in ligand concentration (e.g., neurosteroids) that do not reflect circulating steroids.

In conclusion, ER- $\beta$-IR follows its mRNA expression and is negatively correlated with neuron activity. It is sensitive to changes in osmolality, but this is specific and restricted to MNCs. Thus, it is clear that ER- $\beta$ is regulated in these neurons, both at the level of mRNA and protein, and this is expected to contribute to variable sensitivity of the magnocellular neurosecretory system to $E_{2}$ and/or other endogenous ligands for ER- $\beta$.

\section{References}

Al-Ghoul WM, Meeker RB, Greenwood RS (1997) Differential expression of five $N$-methyl-D-aspartate receptor subunit mRNAs in vasopressin and oxytocin neuroendocrine cells. Brain Res Mol Brain Res 44:262-272.

Alves SE, Lopez V, McEwen BS, Weiland NG (1998) Differential colocalization of estrogen receptor beta (ERbeta) with oxytocin and vasopressin in the paraventricular and supraoptic nuclei of the female rat brain: an immunocytochemical study. Proc Natl Acad Sci USA 95:3281-3286.

Amico JA, Seif SM, Robinson AG (1981) Oxytocin in human plasma: correlation with neurophysin and stimulation with estrogen. J Clin Endocrinol Metab 52:988-993.

Bai G, Kusiak JW (1993) Cloning and analysis of the 5' flanking sequence of the rat $N$-methyl-D-aspartate receptor 1 (NMDAR1) gene. Biochim Biophys Acta 1152:197-200.

Brimble MJ, Dyball RE, Forsling ML (1978) Oxytocin release following osmotic activation of oxytocin neurones in the paraventricular and supraoptic nuclei. J Physiol (Lond) 278:69-78.

Burbach JP, van Schaick H, Lopes da Silva S, Asbreuk CH, Smidt MP (1998) 
Hypothalamic transcription factors and the regulation of the hypothalamo-neurohypophysial system. Adv Exp Med Biol 449:29-37.

Carter DA, Pardy K, Murphy D (1993) Regulation of vasopressin gene expression: changes in the level, but not the size, of vasopressin mRNA following endocrine manipulations. Cell Mol Neurobiol 13:87-95.

Catudioc-Vallero J, Sands JM, Klein JD, Sidorowicz HE, Sladek CD (2000) Effect of age and testosterone on the vasopressin and aquaporin responses to dehydration in Fischer 344/Brown-Norway F1 rats. J Gerontol A Biol Sci Med Sci 55:B26-B34.

Crowley RS, Amico JA (1993) Gonadal steroid modulation of oxytocin and vasopressin gene expression in the hypothalamus of the osmotically stimulated rat. Endocrinology 133:2711-2718.

Decavel C, Curras MC (1997) Increased expression of the N-methyl-Daspartate receptor subunit, NR1, in immunohistochemically identified magnocellular hypothalamic neurons during dehydration. Neuroscience 78:191-202.

Hallbeck M, Blomqvist A (1999) Spinal cord-projecting vasopressinergic neurons in the rat paraventricular hypothalamus. J Comp Neurol 411:201-211.

Hallbeck M, Hermanson O, Blomqvist A (1999) Distribution of preprovasopressin mRNA in the rat central nervous system. J Comp Neurol 411:181-200.

Hamamura M, Nunez DJ, Leng G, Emson PC, Kiyama H (1992) c-fos may code for a common transcription factor within the hypothalamic neural circuits involved in osmoregulation. Brain Res 572:42-51.

Hoffman GE, Lyo D (2002) Anatomical markers of activity in neuroendocrine systems: are we all "fos-ed out"? J Neuroendocrinol 14:259-268.

Hrabovszky E, Kallo I, Hajszan T, Shughrue PJ, Merchenthaler I, Liposits Z (1998) Expression of estrogen receptor-beta messenger ribonucleic acid in oxytocin and vasopressin neurons of the rat supraoptic and paraventricular nuclei. Endocrinology 139:2600-2604.

Jankowski M, Hajjar F, Kawas SA, Mukaddam-Daher S, Hoffman G, McCann SM, Gutkowska J (1998) Rat heart: a site of oxytocin production and action. Proc Natl Acad Sci USA 95:14558-14563.

Jones CW, Pickering BT (1969) Comparison of the effects of water deprivation and sodium chloride imbibition on the hormone content of the neurohypophysis of the rat. J Physiol (Lond) 203:449-458.

Klein M, Pieri I, Uhlmann F, Pfizenmaier K, Eisel U (1998) Cloning and characterization of promoter and 5'-UTR of the NMDA receptor subunit epsilon 2: evidence for alternative splicing of $5^{\prime}$-non-coding exon. Gene 208:259-269.

Kuiper GG, Enmark E, Pelto-Huikko M, Nilsson S, Gustafsson JA (1996) Cloning of a novel receptor expressed in rat prostate and ovary. Proc Natl Acad Sci USA 93:5925-5930.

Kushner PJ, Agard DA, Greene GL, Scanlan TS, Shiau AK, Uht RM, Webb P (2000) Estrogen receptor pathways to AP-1. J Steroid Biochem Mol Biol 74:311-317.

Laflamme N, Nappi RE, Drolet G, Labrie C, Rivest S (1998) Expression and neuropeptidergic characterization of estrogen receptors (ERalpha and ERbeta) throughout the rat brain: anatomical evidence of distinct roles of each subtype. J Neurobiol 36:357-378.

Lephart ED (1996) A review of brain aromatase cytochrome P450. Brain Res Brain Res Rev 22:1-26.

Liposits Z (1993) Ultrastructure of hypothalamic paraventricular neurons. Crit Rev Neurobiol 7:89-162.

Nomura M, Korach KS, Pfaff DW, Ogawa S (2003) Estrogen receptor beta (ERbeta) protein levels in neurons depend on estrogen receptor alpha (ERalpha) gene expression and on its ligand in a brain region-specific manner. Brain Res Mol Brain Res 110:7-14.

O'Keefe JA, Crowley RS, Hrivnak P, Kim NB, Amico JA (1995) Effect of testosterone and its metabolites upon the level of vasopressin messenger ribonucleic acid in the hypothalamus of the hyperosmotically stimulated male rat. Neuroendocrinology 61:405-411.

Osterlund M, Kuiper GG, Gustafsson JA, Hurd YL (1998) Differential distribution and regulation of estrogen receptor-alpha and -beta mRNA within the female rat brain. Brain Res Mol Brain Res 54:175-180.

Patisaul HB, Whitten PL, Young LJ (1999) Regulation of estrogen receptor beta mRNA in the brain: opposite effects of 17beta-estradiol and the phytoestrogen, coumestrol. Brain Res Mol Brain Res 67:165-171.

Patisaul HB, Dindo M, Whitten PL, Young LJ (2001) Soy isoflavone supplements antagonize reproductive behavior and estrogen receptor alpha- and beta-dependent gene expression in the brain. Endocrinology 142:2946-2952.
Paxinos G, Watson C (1986) The rat brain in stereotaxic coordinates, Ed 2. London: Academic.

Paxinos G, Watson C (1996) The rat brain in stereotaxic coordinates, Ed 3. London: Academic.

Russell JA, Leng G (1998) Sex, parturition and motherhood without oxytocin? J Endocrinol 157:343-359.

Russell JA, Blackburn RE, Leng G (1989) Ablation of the region anterior and ventral to the third ventricle (AV3V region) does not impede parturition in rats. J Endocrinol 121:109-115.

Safe S (2001) Transcriptional activation of genes by 17 beta-estradiol through estrogen receptor-Sp1 interactions. Vitam Horm 62:231-252.

Sawchenko PE, Brown ER, Chan RK, Ericsson A, Li HY, Roland BL, Kovacs KJ (1996) The paraventricular nucleus of the hypothalamus and the functional neuroanatomy of visceromotor responses to stress. Prog Brain Res 107:201-222.

Shapiro RA, Xu C, Dorsa DM (2000) Differential transcriptional regulation of rat vasopressin gene expression by estrogen receptor alpha and beta. Endocrinology 141:4056-4064.

Shaw G, Renfree MB, Leihy MW, Shackleton CH, Roitman E, Wilson JD (2000) Prostate formation in a marsupial is mediated by the testicular androgen 5 alpha-androstane- 3 alpha, 17 beta-diol. Proc Natl Acad Sci USA 97:12256-12259.

Shughrue PJ, Merchenthaler I (2001) Distribution of estrogen receptor beta immunoreactivity in the rat central nervous system. J Comp Neurol 436:64-81.

Shughrue PJ, Komm B, Merchenthaler I (1996) The distribution of estrogen receptor-beta mRNA in the rat hypothalamus. Steroids 61:678-681.

Shughrue PJ, Lane MV, Scrimo PJ, Merchenthaler I (1998) Comparative distribution of estrogen receptor-alpha (ER-alpha) and beta (ER-beta) mRNA in the rat pituitary, gonad, and reproductive tract. Steroids 63:498-504.

Skowsky WR, Swan L, Smith P (1979) Effects of sex steroid hormones on arginine vasopressin in intact and castrated male and female rats. Endocrinology 104:105-108.

Sladek CD (2000) Antidiuretic hormone: synthesis and release. In: Handbook of physiology, Sec 7, Endocrinology, Vol III, Hormonal regulation of water and electrolyte balance (Fray JCS, ed), pp 436-495. Oxford: Oxford UP.

Somponpun S, Sladek CD (2002) Role of estrogen receptor-beta in regulation of vasopressin and oxytocin release in vitro. Endocrinology 143:2899-2904.

Stedronsky K, Telgmann R, Tillmann G, Walther N, Ivell R (2002) The affinity and activity of the multiple hormone response element in the proximal promoter of the human oxytocin gene. J Neuroendocrinol 14:472-485.

Swanson LW, Kuypers HG (1980) The paraventricular nucleus of the hypothalamus: cytoarchitectonic subdivisions and organization of projections to the pituitary, dorsal vagal complex, and spinal cord as demonstrated by retrograde fluorescence double-labeling methods. J Comp Neurol 194:555-570.

Swanson LW, Sawchenko PE (1983) Hypothalamic integration: organization of the paraventricular and supraoptic nuclei. Annu Rev Neurosci 6:269-324.

Swenson KL, Sladek CD (1997) Gonadal steroid modulation of vasopressin secretion in response to osmotic stimulation. Endocrinology 138:2089-2097.

Swenson KL, Badre SE, Morsette DJ, Sladek CD (1998) N-methyl-Daspartic acid stimulation of vasopressin release: role in osmotic regulation and modulation by gonadal steroids. J Neuroendocrinol 10:679-685.

Van Tol HH, Voorhuis DT, Burbach JP (1987) Oxytocin gene expression in discrete hypothalamic magnocellular cell groups is stimulated by prolonged salt loading. Endocrinology 120:71-76.

Verbalis JG (1984) An experimental model of syndrome of inappropriate antidiuretic hormone secretion in the rat. Am J Physiol 247:E540-E553.

Verbalis JG, Mangione MP, Stricker EM (1991) Oxytocin produces natriuresis in rats at physiological plasma concentrations. Endocrinology 128:1317-1322.

Viau V, Sawchenko PE (2002) Hypophysiotropic neurons of the paraventricular nucleus respond in spatially, temporally, and phenotypically differentiated manners to acute vs. repeated restraint stress: rapid publication. J Comp Neurol 445:293-307.

Wade CE, Keil LC, Ramsay DJ (1983) Role of volume and osmolality in the control of plasma vasopressin in dehydrated dogs. Neuroendocrinology 37:349-353. 